\title{
Comparison of vitamin A intake from breast milk and from complementary foods in the diet of six-month old infants in Jujuy and Buenos Aires
}

\author{
Carola Beatriz Greco, M.D. ${ }^{a}$, Prof.r Laura Beatriz López, M.D. ${ }^{a}$, Viviana Rodríguez, Pharmacist ${ }^{a}$, \\ Luis Dyner, M.D. ${ }^{a}$, Verónica Gibson, M.D. ${ }^{b}$, Luisa Virginia Pinotti, B.S. ${ }^{c}$, and \\ Prof. Patricia Ana Ronayne de Ferrer, M.D. ${ }^{a}$
}

\begin{abstract}
The objective of this study was to compare the dietary pattern of two socio-culturally different populations, focusing on the vitamin A intake from breast milk and from the most commonly consumed complementary foods. Dietary surveys on sixmonth old infant feeding were administered to breastfeeding mothers in Jujuy $(n=44)$ and Buenos Aires $(n=95)$. For milk, the level of retinol was determined by liquid chromatography; for foods, calorie and vitamin A values were estimated. In Jujuy and Buenos Aires, $75.6 \%$ and $64.5 \%$ of infants were receiving complementary foods at six months old, and more than 50\% had started earlier. Milk retinol ranged from 0.02 to $1.19 \mu \mathrm{g} /$ $\mathrm{mL}$ and from 0.09 to $1.94 \mu \mathrm{g} / \mathrm{mL}$ in mothers in Jujuy and Buenos Aires, respectively.Values $<0.30 \mu \mathrm{g} / \mathrm{mL}$, indicative of vitamin A deficiency, were observed in $67.4 \%$ and $26.1 \%$ of milk samples, respectively. Usually consumed foods may provide sufficient vitamin A for Buenos Aires participants, but insufficient for those in Jujuy.
\end{abstract}

Key words: breastfeeding, vitamin A, dietary patterns.

http:/ /dx.doi.org/10.5546/aap.2014.eng.439

\section{INTRODUCTION}

Vitamin A (retinol) is an essential micronutrient necessary for the normal functioning of the visual system, adequate growth and development, epithelial cell integrity, immunity and reproduction. ${ }^{1}$ Breastfed infants and breastfeeding women are considered risk groups for vitamin A deficiency.

a. Chair of Bromatology, School of Pharmacy and Biochemistry, Universidad de Buenos Aires. Argentina.

b. Sanatorio Mater Dei. City of Buenos Aires, Argentina.

c. Centro de Investigación Sobre Problemáticas Alimentarias-Nutricionales (CISPAN, FeedingNutritionResearch Center), Department of Nutrition, School of Medicine, Universidad de Buenos Aires.

E-mail Address:

Carola Beatriz Greco, M.D.: cgreco@ffyb.uba.ar

Conflict of Interest: None

Funding: Universidad de Buenos Aires.

Project no. 20020100100166.

Received: 10-17-2013

Accepted: 3-17-2014
A negative correlation has been demonstrated between morbidity and mortality in children and their retinol nutritional status. ${ }^{2}$ The level of vitamin A in breast milk depends on maternal intake. ${ }^{3}$

Complementary foods given as of six months old should have an adequate nutritional quality. Vitamin A is one of several crucial micronutrients. ${ }^{3,4}$

Differences have been observed in dietary patterns of diverse socio-economic and/or regional settings, which are reflected in children upbringing. ${ }^{4}$

The objective of this study was to compare the dietary pattern of two socio-culturally different populations, focusing on vitamin A intake from breast milk and from the most commonly consumed complementary foods.

\section{POPULATION AND METHODS Design}

This was a cross-sectional study conducted between February 2008 and December 2011. Both populations were made up of breastfeeding mothers at 6 months post-partum: a) native women assisted at Hospital de Maimará or at rural health posts in Jujuy; and b) women seen at the outpatient offices of Sanatorio Mater Dei in Buenos Aires.

Participants were selected on a consecutive randomization basis. Inclusion criteria were: breastfeeding, apparently healthy women with infants aged 6 months \pm 5 days old, being older than 18 years old; and term birth (primiparous and multiparous women). Exclusion criteria were: having a disease; not breastfeeding; preterm or multiple birth; and being a teenager.

\section{Population}

The minimum number of women for each population (80) was estimated based on DawsonSaunders' and Trapp's recommendations. ${ }^{5}$

\section{Materials and methods}

A structured questionnaire was administered 
to mothers at six months post-partum. The survey was specifically designed for this study to gather information on the frequency of breastfeeding (number of feedings/day), infant eating habits, and age at initiation of complementary feeding (see Annex). On the day of the survey, a breast milk sample was collected in the morning by manual expression of one breast. The sample was stored at $-20{ }^{\circ} \mathrm{C}$ and protected from direct light until processing.

The level of retinol was determined by liquid chromatography. ${ }^{6}$ Milk retinol levels were considered adequate if they were $\geq 0.40 \mu \mathrm{g} / \mathrm{mL}$, marginal if $0.30-0.39 \mu \mathrm{g} / \mathrm{mL}$, and deficient if $<0.30 \mu \mathrm{g} / \mathrm{mL}^{7}$

The most commonly consumed foods were determined according to the survey.The calorie value of foods was calculated based on its composition using official methods ${ }^{8}$ and Atwater factors ( $4 \mathrm{kcal} / \mathrm{g}$ for protein and carbohydrate, $9 \mathrm{kcal} / \mathrm{g}$ for fat).Vitamin A content was estimated using food composition tables ${ }^{9}$ and nutrient density expressed as $\mu \mathrm{g}$ RAE/100 kcal (RAE:retinol activity equivalents $/ 100 \mathrm{kcal}$ ).

\section{Ethical considerations}

Mothers were asked to provide their informed consent. Authorization was given in advance by the ethics committees of participating sites.

\section{Statistical analysis}

A non-parametric Mann-Whitney's test and a maximum likelihood chi-square test were used for milk retinol results (significance level: 5\%). The Infostat software was used (version 2008, UNC).

\section{RESULTS}

The total number of participants was 95 in Buenos Aires, but 44 in Jujuy for different reasons: difficulty attending periodic visits to the doctor, changes in the study staff working at the site, loss of samples due to inadequate cold chain.

At 6 months old, $8.9 \%$ and $18.4 \%$ of infants from Jujuy and Buenos Aires, respectively, were exclusively breastfed.In most cases, the frequency was more than three feedings a day. In Jujuy and Buenos Aires, respectively, $75.6 \%$ and $64.5 \%$ of infants received complementary foods and/or some sort of formula. In that same order, $35.6 \%$ and $19.7 \%$ had started with these at 5 months old, while also in Jujuy, $10 \%$ had started even earlier. Only in Jujuy, infants drank tea or mate infusions.

Both groups of mothers referred that they offered their infants only one daily food, which was usually a salted and/or sweet pap. The most commonly consumed foods in Jujuy were part of the "family pot": corn mash (ground white corn grains), stew with corn (corn boiled with lime or ash) and tripe (guts), and stew with noodles. Other foods were also consumed but less frequently. In Buenos Aires, the most commonly consumed foods were mashed squash, fruits and milk with breakfast cereals (Figure 1).

Retinol ranged between 0.02 and $1.19 \mu \mathrm{g} /$ $\mathrm{mL}$ (median: $0.20 \mu \mathrm{g} / \mathrm{mL}$ ) in milk samples from Jujuy, and between 0.09 and $1.94 \mu \mathrm{g} / \mathrm{mL}$ (median:0.44 $\mu \mathrm{g} / \mathrm{mL}$ ) in samples from Buenos Aires, with a significant difference $(p=0.0005)$. Milk retinol levels were $<0.30 \mu \mathrm{g} / \mathrm{mL}$ in $67.4 \%$ and $26.1 \%$ of mothers from Jujuy and Buenos Aires; between 0.30 and $0.39 \mu \mathrm{g} / \mathrm{mL}$ in $4.7 \%$ and $18.5 \%$, and $>0.40 \mu \mathrm{g} / \mathrm{mL}$ in $27.9 \%$ and $55.4 \%$, respectively, with significant differences observed between both groups $(p<0.0001)$.

Table 1 shows vitamin A nutrient density ( $\mu \mathrm{g}$ RAE/100 kcal) of foods consumed in Jujuy and Buenos Aires.

\section{DISCUSSION}

An early introduction of complementary foods was observed in both populations. This is consistent with the National Survey on Nutrition and Health in Argentina (ENNyS, for its acronym in Spanish), which estimated that up to $31 \%$ of infants are exclusively breastfed until they are six months old ${ }^{10}$ and showed that $70 \%$ had started receiving complementary foods before that age. Such early introduction pattern has been observed in different countries, with a high diversity in the type of foods offered. ${ }^{11}$

Differences were observed in the foods most frequently consumed by each population; the most common ones (potato, pumpkin, fruits) were consumed with time-varying periodicity. According to the ENNyS, complementary foods introduced at an early stage are yoghourt, cooked vegetables, purée, and fruit juice. ${ }^{10}$ Previous studies showed similar results. ${ }^{12,13}$ In developing countries, it is usual to prepare pap with cereals and root vegetables, which provides a low level of micronutrients and excess fiber. ${ }^{11}$

In Jujuy, it is common to offer infants the same foods consumed by the rest of the family; adults usually give babies a taste of their meals, and soup is the first complementary food to breastfeeding. ${ }^{14}$ This is consistent with our results. Milk retinol ranges between 0.40 and $0.70 \mu \mathrm{g} /$ 
$\mathrm{mL}$ in populations who have a sufficient vitamin A intake. ${ }^{1,7}$ In Buenos Aires, the median level was within such range; however, in Jujuy, it was lower than $0.30 \mu \mathrm{g} / \mathrm{mL}$, which is representative of populations with vitamin $\mathrm{A}$ deficiency. ${ }^{7}$ Few studies have been conducted in Argentina in this field. The mean value detected in samples from a milk bank, prior to pasteurization, was $0.37 \mu \mathrm{g} / \mathrm{mL} .{ }^{15}$ In a rural population from Santiago del Estero, values up to $0.60 \mu \mathrm{g} / \mathrm{mL}$ were observed, with $19.3 \%$ below $0.40 \mu \mathrm{g} / \mathrm{mL} .{ }^{6}$ In our study, although the expected sample size was not reached in Jujuy, highly inadequate percentages were observed, with significant differences between both populations. This may be indicative of an inadequate maternal

FIGURE 1. Most commonly consumed foods by infants in Jujuy and Buenos Aires

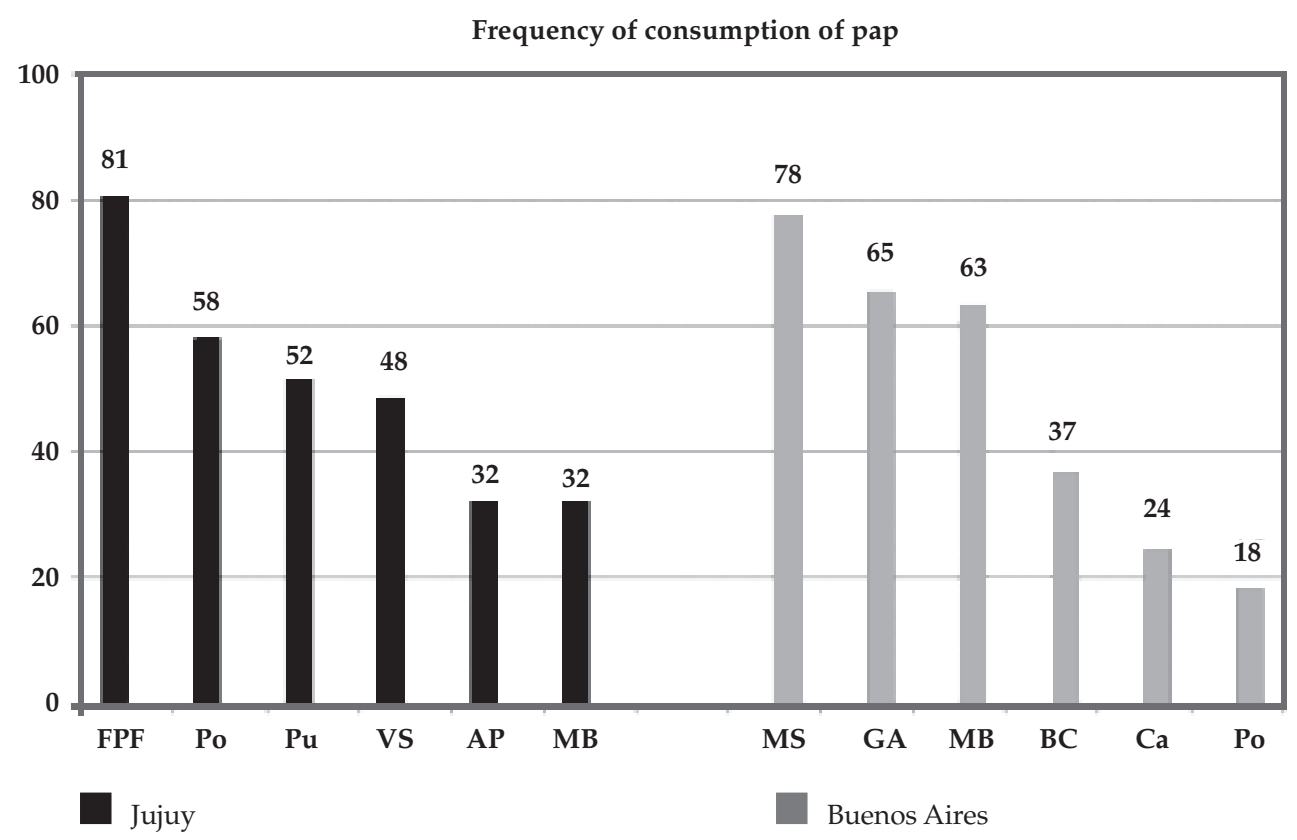

Jujuy. FPF: family pot foods; Po: potato; Pu: pumpkin; VS: vegetable soup; AP: apple purée; MB: mashed banana.

Buenos Aires. MS: mashed squash with oil; GA: grated apple; MB: mashed banana; BC: breakfast cereals with milk (corn and rice); Ca: carrot; Po: potato.

TABLE 1. Calorie intake, vitamin A content and estimated vitamin A nutrient density in most commonly consumed foods by infants in Jujuy and Buenos Aires

\begin{tabular}{lccc}
\hline & $\begin{array}{c}\mathrm{E}^{*} \\
(\mathbf{k c a l} / \mathbf{1 0 0} \mathbf{g})\end{array}$ & $\begin{array}{c}\text { Vitamin A } \\
\left(\boldsymbol{\mu g} \mathbf{R A E}^{* *} / \mathbf{1 0 0} \mathbf{g}\right)\end{array}$ & $\begin{array}{c}\text { Vitamin A } \\
\left(\boldsymbol{\mu g} \mathbf{R A E}^{* *} / \mathbf{1 0 0} \mathbf{k c a l}\right)\end{array}$ \\
\hline Corn mash & 56 & 37 & 66 \\
Stew with corn and tripe & 108 & 131 & 121 \\
Stew with noodles & 103 & 127 & 124 \\
Mashed squash with oil & 44 & 142 & 479 \\
Breakfast corn cereals & 101 & 142 & 141 \\
Breakfast rice cereals & 103 & & 137 \\
\hline
\end{tabular}

*E: energy.

**RAE: retinol activity equivalents. 
vitamin A intake, consistent with the ENNyS.

In view of this situation, complementary foods should provide sufficient quantities of retinol. According to the World Health Organization, ${ }^{1}$ nutrient density should be $31 \mu \mathrm{g}$ RAE/100 kcal for infants aged 6-8 months old, equivalent to $0.50 \mu \mathrm{g} / \mathrm{mL}$ of retinol in milk. ${ }^{3}$ Given that the median value was lower in both groups, adequate values were re-estimated: $131 \mu \mathrm{g}$ RAE/100 kcal in Jujuy, and $51 \mu \mathrm{g}$ RAE/100 kcal in Buenos Aires. When comparing results shown in Table 1, it can be seen that the minimum required density is not reached in Jujuy. By contrast, the minimum required density is much higher than the recommended in Buenos Aires.

As per gastric capacity at this age, the minimum energy density of complementary foods should be $0.8 \mathrm{kcal} / \mathrm{g},{ }^{4}$ which is not met by corn stew nor mashed squash with oil (Table 1).

\section{CONCLUSIONS}

In both groups, less than $50 \%$ of infants started complementary feeding at six months old, with differences observed in the type of foods provided. Insufficient retinol levels that did not meet infant requirements were observed in $67.4 \%$ and $26.1 \%$ of milk samples from Jujuy and Buenos Aires. In Jujuy, the most commonly consumed foods do not provide enough vitamin A to cover such needs. Therefore, it is recommended that foods that provide vitamin A be introduced in mothers' and/or infants' diets.

\section{Acknowledgments}

We would like to thank health care professionals of Hospital de Maimará and participating mothers.

\section{REFERENCES}

1. World Health Organization and Food and AgricultureOrganization of the United Nations. Vitamin A. En: WorldHealth Organization, ed. Vitamin and mineral requirementsin human nutrition. $2^{\text {nd }}$ ed. Hong Kong. World Health Organization 2004; Págs.17-44.
2. West KP Jr. Extent of vitamin A deficiency among preschoolchildren and women of reproductive age. J Nutr 2002;132(9 Suppl): 2857S-66S.

3. World Health Organization. Complementary feeding ofyoung children in developing countries; a review of currentscientific knowledge. Geneva; 1998.

4. DeweyKG,BrownKH.Updateontechnicalissuesconcerning complementary feeding of young children indeveloping countries and implications for interventionprograms. Food Nutr Bull 2003;24(1):5-28.

5. Dawson-Saunders B,Trapp R. Estimación y comparaciónde medias. En Lazo de la Vega Sánchez M, ed. Bioestadística Médica. 4a ed. México DF: El Manual Moderno; 2005. Págs.141-3.

6 . López LB, Baroni AV, Rodríguez VG, Greco CB, et al.Desarrollo y validación de un método por HPLC parala determinación de vitamina A en leche materna. Suaplicación a una población rural de Argentina. Arch Latinoamer Nutr 2005;55(2):140-3.

7. World Health Organization. Indicators for assessingvitamin A deficiency and their application in monitoringand evaluating intervention programmes. Geneva; 1996.

8. Horwitz W. Official Methods of Analysis of AOAC International. 17thed. Maryland: AOAC International;2000.

9. Argenfoods. Tabla deComposición de Alimentos delaUnlu [Internet]. Luján: Universidad Nacional de Luján,c2010. [Accessed on: March 15, 2012]. Available at: http:/ / www. unlu.edu.ar/ argenfood/Tablas/Tabla.htm.

10. MangialavoriG, AbeyáGilardon E, BiglieriGuidet A,Durán $P$, et al. La alimentación de los niños menoresde 2 años. Resultados de la Encuesta Nacional de Nutricióny Salud - ENNyS 2010. Buenos Aires: Ministerio de Salud;2010.

11. RonaynedeFerrerPA,GrecoCB,BinaghiMJ.Complementary feeding in developing countries. En:Filip R, ed. Multidisciplinary Approaches on Food Science and Nutrition for the XXI Century. Kerala:Transworld ResearchNetwork; 2011. Págs.245-73.

12. Albarenque S, Mas L, Ferreyra M, Marchisio M, et al. Lactancia materna y alimentación complementaria. Arch Argent Pediatr 2005;103(3):257-8.

13. Macias SM, Rodríguez S, Ronayne de Ferrer PA. Patrón de alimentación e incorporación de alimentos complementarios en niños lactantes de una población de bajos recursos. Rev Chil Nutr 2013;40(3):235-42.

14. Naumann S, Pinotti L. Lactancia materna y alimentación complementaria en la Quebrada de Humahuaca: una aproximación cualitativa. Rev Argent Salud Pública 2012;3(12):6-14

15. Matamoros N, González H. Contenido de vitamina A en leche materna madura post pasteurización. Adecuación a los requerimientos nutricionales del lactante. Rev Argent Salud Pública. En prensa. 


\section{Annex}

\section{Dietary survey of infants breastfed for the first six months of life}

\section{Breastfeeding and complementary feeding}

\begin{tabular}{ll}
\hline Date: & Date of sample expression: \\
\hline Data about the mother & \\
\hline Name: & Weight before pregnancy: \\
\hline City: & Weight after giving birth: \\
\hline Age: & Height: \\
\hline Telephone number: & E-mail address: \\
\hline Data about the baby & \\
\hline Name: & Current weight: \\
\hline Date of birth: & Current height: \\
\hline Weight at birth: & Current head circumference: \\
\hline Height at birth: & Gestational age: \\
\hline Head circumference: & \\
\hline Remarks: & \\
\hline
\end{tabular}

1. Do you breastfeed your baby? Yes.__ No.

How many times a day? Up to three times.__ More than three times._

2. Do you bottle-feed your baby? Yes.___ No.

What do bottles contain? Check one or more options, as applicable:

Fluid cow's milk. ___ Powdered cow's milk.___ Another animal's milk.

Fluid formula. ___ Brand name of formula:

Powdered formula. ___ Brand name of formula:

Tea. ___ Mate infusion.

How do you prepare infusions? Do you dilute milk?

Yes.__ No.__ How? 1/2.___ 1/3. ___ Other:

Do you add oil? Yes.__ No.__ How many teaspoonfuls?

Do you add sugar? Yes.__ No. ___ How many teaspoonfuls?

At what age did you start bottle-feeding your baby? At months old.

How many times a day? What amount? $\mathrm{cm} 3$.

3. Do you feed solid or semi-solid (pap) food to your baby? Yes.__ No.

At what age did you start? At ___ months old. How many times a day?

How much of these foods (measured as tablespoonfuls) does your baby eat?

Do you give your baby a taste of the family food? Yes.__ No.__ $\left(^{*}\right)$

What type of food and when?

Describe in detail how you prepare salted or sweet pap for your baby.

$\left.{ }^{*}\right)$ This question was included only for the Jujuy group as recommended by the interdisciplinary team anthropologists and nutritionists. 